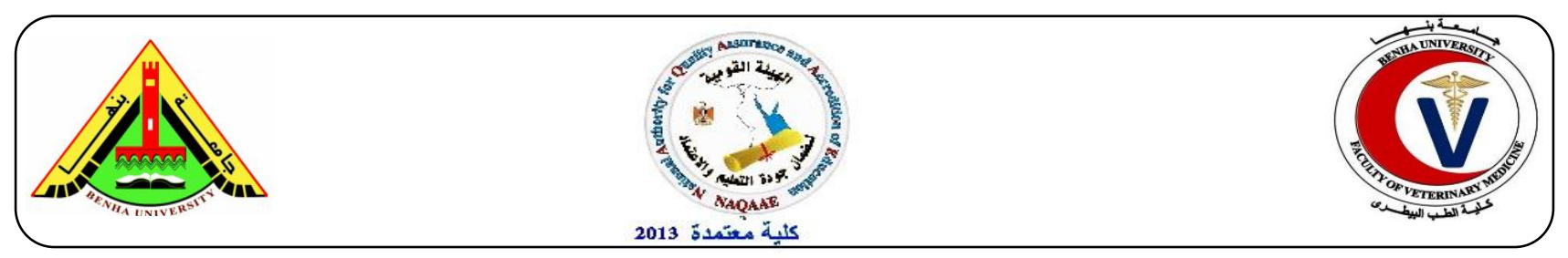

\title{
Rectal, Anal Gland: A Corrective Morphological Study in New Zealand Rabbit (Oryctolagus cuniculus)
}

\author{
Hanaa M. El-Ghazali ${ }^{{ }^{*}}$ and Sozan A. Ali $^{2}$ \\ ${ }^{1}$ Department of Anatomy and Embryology, Faculty of Veterinary Medicine, Zagazig University \\ ${ }^{2}$ Department of Histology, Faculty of Veterinary Medicine, Zagazig University
}

\section{A B S T R A C T}

In order to achieve the main objective of our research is to prove that rabbits possess rectal glands not anal glands. Our work was carried out on fifteen healthy adult New Zealand rabbits (Oryctolagus cuniculus) of both sexes and with variable ages. The glands were macro and microscopically examined. Also the measurements of the gland and the rectum (length/cm) were obtained. The rectal glands were elongated oval in outline and present on the lateral sides of the rectum and ended at the anorectal junction. Microscopically, the rectal gland was merocrine in nature and divided into many lobules that composed of different exocrine secretory. The ducts of the gland were numerous in the anterior two third and were scanty in the posterior one third.

Keywords: Rectum, Anal gland, scent, Fistula.

(http://www.bvmj.bu.edu.eg)

(BVMJ-34(2): 221-233, 2018)

\section{INTRODUCTION}

The number of rabbits and chinchillas as pets is increased in the last years and use as an experimental model in various researches (Stan, Damian, Gudea, Dezdrobitu, Bob, Martonos, Bochis and Pogana, 2014).

There is a misunderstanding in many papers study the rectal gland of rabbit as anal gland, for example Mykytowycz (1966) who reveal that, the anal glands are very large and well developed as a separate organ present laterally to the rectum. Also the books which deal with the anatomy of rabbit don't describe the rectal gland when it discusses the rectum. It point to the gland as anal gland not rectal as Mclaughlin and Chiasson (1979).

The nomenclature of the gland is based on its position. In balady rabbit, the rectal glands are elongated and situated lateral to the terminal part of the rectum (Balah, Ammar, Bareedy and Anis, 1986). The anal glands are repeatedly scattered in the internal sphincter (McColl, 1965). In human, due to the ramification of the gland in the muscles they are called intramuscular anal glands. The anal glands have important role in the production of fistulae in man (Parks, 1961). In dog, there are large anal glands or anal sacs which present on each side of the anal canal and open onto the anal verge (McColl, 1965).

Many authors confirmed the importance of anal scent gland's secretions as territorial marker (Bourliére, 1955; Mykytowycz, 1966; Mykytowycz, Hesterman, Gambale and Dudzinski, 1976 and John and Ebling, 1988) 
and its surgical removal don't affect the defecation (Takaki and Tagawa, 1961).

Also fishes and some insects have rectal glands. The spiny dog fish has a rectal gland that specially secretes sodium chloride twice the plasma concentration (Burger and Hess, 1960). The rectal gland of elasmobranchs is most important in the osmoregulation of these fishes (Burger and Hess, 1960 and Burger, 1962). The gland is formed of secretory tubules which are surrounded the central excretory duct then encircle by a dense capillary network (Gerzeli, Destefano, Bolognani, Koenig, Gervaso and OmodeoSalé, 1976). In most insects, the rectal gland plays an important role in water reabsorption (Wigglesworth, 1965). The rectal glands act as a source of sex trail pheromones which secrete during courting in ants (Billen and Morgan,1998 and Billen, 2009)and the sexually mature males of Bactrocera papaya (male fruit fly) (Khoo and Tan, 2005).

The literatures dealing with the anatomy of the rectal gland of rabbit are scanty. So the aim of this work is the full description of the rectal glands to give a more comprehensive picture of these glands and corrects this error in nomenclature of rectal glands as anal glands in the most research papers which deal with the scent glands of rabbit.

\section{Materials and methods}

The present study was carried out on fifteen healthy adult New Zealand rabbits (Oryctolagus cuniculus) of both sexes and with variable ages. The animals were collected from the animal laboratory house in Faculty of Veterinary Medicine, Zagazig University, Egypt.

\subsection{Gross morphological examinations:}

The animals were sedated and anesthetized with $3 \mathrm{mg} / \mathrm{kg}$ xylazine i.v followed by 3 $\mathrm{mg} / \mathrm{kg}$ ketamine i.v injection through the ear vein (Hall, Clarke and Trim, 2001). After weighting of animals by using the digital scale, the exsanguinations from the common carotid artery under complete anesthesia were applied. Ten rabbits were used for the gross morphology of the gland to detect its shape, colour, position and relation. Two rabbits dissected freshly to determine colour and shape of the gland in the fresh state. Eight rabbits were injected by $10 \%$ formalin through the common carotid artery till the complete rigidity of animals. The specimens were preserved in a mixture of $10 \%$ formalin, $3 \%$ glycerine, $1 \%$ thymol. Also these ten specimens used for detection of the different measurements of the gland and the rectum (length/cm) by using the graduated tape.

Three rabbits were injected with gum milk (Latex 60\%) colored green with Scib paints through rectum after closure of the anus and colon by artery forcipes. The injected rabbits were fixed in a mixture of $10 \%$ formalin, $3 \%$ glycerine, $1 \%$ thymol and dissected for the description of the ducts of the gland. The obtained animals used in this study were carefully handled by following to the rules of the ethics committee for animal studies at Zagazig University, Egypt.

By using the SPSS software program (version 16.0; Chicago,USA), the collected data were analyzed for detection of the mean value and the standard deviation.

Nomina Anatomica Veterinaria (2012) was used for the anatomical nomenclature in this work whenever possible.

\subsection{Light microscopic examination:}

Rectum with the rectal glands and anus of two rabbits were fixed in Bouin's fluid for four to six hours. The specimens were cut as cross sections of rectum with the anterior part, middle part and posterior part of the gland on each side then cross sections at the anorectal junction and anus finally longitudinal section of the gland. 
Then these sections immersed in neutral buffered formalin $10 \%$. The specimens were dehydrated in ascending grades of alcohols, cleared in three changes of Xylol and embedded in paraffin wax. Sections of five to six microns thickness were obtained, then mounted and stained with the following stains:

A- Harris` haematoxylin and eosin (H\&E) stain, as routine stain for general histological studies.

B- Periodic Acid Schiff (PAS) technique for detection of both acid and neutral mucopolysaccharides.

C- Crossmon's trichrome stain for collagen fibres and muscle fibres.

The preceding methods of processing and staining were used as summarized by Crossmon (1937), Drury and Wallington (1980), Bancroft and Gamble (2001) and Kiernan (2008).

\section{RESULTS}

\section{Gross morphological observations}

The rectum of rabbit was protruded outside the pelvic cavity accompanied its rectal glands (laterally), the vagina or penis (ventrally) in female and male respectively and the tail (dorsally) (Fig.1 A, B, C, D and E). A triangular furrow was formed in between the rectum, vagina or penis which it was occupied by the inguinal gland (Fig. $1 \mathrm{~A}$ and B). There was a band of muscle fibers, extended from the tail surrounding the rectal gland, rectum and ended in the ventral midline of vagina in female or penis in male (M. levator ani) (Fig.1 D and E). The rectal glands were elongated oval in outline and present on the lateral sides of the rectum (Fig.2 A, B, C, D, E, F, G and H). Each gland extended from the third to the sixth caudal vertebra and ended at the anorectal junction (Fig.2 A and D). Its relative length was $3.020 \pm 0.5308 \mathrm{~cm}$ (Table 1). It appeared lobulated with dorsal and ventral borders, medial and lateral surfaces also anterior and posterior poles. The posterior pole was broader than the anterior one which seemed to be rounded (Fig.2 $\mathrm{B}$ and $\mathrm{C}$ ). The posterior poles of the glands were closed together ventral to the rectum while dorsally they were diverged (Fig.2 $\mathrm{E}$ and F). It was gray in colour in fresh state (Fig.1C) but after fixation with formalin it appeared brownish (Fig.2 B, C, D, E and F). Small part of the gland was cranially related to the pelvic surface of the ischium and M. obturatorius internus (Fig.2 G and $\mathrm{H}$ ). The anterior pole of the gland was dorsolaterally located to $\mathrm{M}$. ishiocavernosus which was large obvious in male rabbit (Fig.1 E). The glands were related to the tail muscles dorsally (M.sacrocaudalis ventralis lateralis) (Figs.2 $\mathrm{H}$ and 3A).The external longitudinal muscles of the rectum covered its wall dorsally and ventrally inbetween the right and left glands (Fig.3 A). The inguinal gland was allied to the rectal gland ventrolaterally in female and male (Fig.3 B and C). The anterior two thirds of the gland were opened between the external longitudinal muscles of the rectum and the wall of it dorsally by several ducts that opened into the rectum through only one duct (Fig.3 D, E and F).

\section{Light microscopic observations}

The rectal glands were covered by thick connective tissue capsule with few vascularity and thin septa release from it which divide the glands into many lobules (Fig.4A). These lobules composed of different exocrine secretory unit (acini) which were lined with clear layer of simple cuboidal epithelium with prominent spherical nuclei (Fig. 4B). Some of these acini contained secretions in their lumen and most of them were free (Fig. 4C and D) where these secretions gave positive reactions with PAS (Fig. 5A and B). Supporting loose connective tissues were present in-between these acini and some collagenic fibers 
surrounded the glands (Fig. 5C and D). Skeletal muscle fibers (Fig. 6A) and abundant of fat cells (Fig. 6B) were noticed. These glands of merocrine-type, with interlobular and intralobular duct system (Fig. 6C and D). Some ducts were lined with large number of prismatic epithelial cells containing ovoid nuclei situated in the lower two third of the cell body at the anterior two third of the gland (Fig.7A) and other were lined with simple cuboidal epithelium (Fig. 6C). While at the Zealand rabbit with consideration to sex, age and weight of rabbits.

\begin{tabular}{|c|c|c|c|c|c|c|}
\hline \multirow[t]{3}{*}{ No. } & \multirow[t]{3}{*}{ Sex } & \multirow{3}{*}{$\begin{array}{l}\text { Age/ } \\
\text { Year(Y) } \\
\text { and } \\
\text { Month(M) }\end{array}$} & \multirow{3}{*}{$\begin{array}{l}\text { Body } \\
\text { weight/ } \\
\text { Kgm }\end{array}$} & \multirow{3}{*}{$\begin{array}{l}\text { Length of } \\
\text { rectum/ } \mathrm{cm}\end{array}$} & \multicolumn{2}{|c|}{ Length of rectal glands $/ \mathrm{cm}$} \\
\hline & & & & & Right & Left \\
\hline & & & & & & \\
\hline \multirow[t]{2}{*}{1} & \multirow{2}{*}{ Female } & 1Yand & 3.700 & 5 & 3.5 & 3.5 \\
\hline & & $2 \mathrm{M}$ & & & & \\
\hline 2 & Female & $8 \mathrm{M}$ & 2.000 & 2.8 & 2.1 & 2.1 \\
\hline 3 & Female & $1 \mathrm{Y}$ & 3.600 & 5 & 3 & 3 \\
\hline \multirow[t]{2}{*}{4} & \multirow{2}{*}{ Female } & 1Yand & 3.800 & 5.5 & 3.5 & 3.5 \\
\hline & & $6 \mathrm{M}$ & & & & \\
\hline \multirow[t]{2}{*}{5} & \multirow{2}{*}{ Female } & 1Yand & 3.500 & 5 & 3 & 3 \\
\hline & & $6 \mathrm{M}$ & & & & \\
\hline 6 & Male & $1 \mathrm{Y}$ & 3.600 & 7 & 4 & 4 \\
\hline 7 & Male & $10 \mathrm{M}$ & 2.250 & 4.7 & 2.7 & 2.7 \\
\hline 8 & Male & $1 \mathrm{Y}$ & 3.300 & 4.8 & 2.8 & 2.8 \\
\hline 9 & Male & $1 \mathrm{Y}$ & 3.350 & 4.9 & 2.9 & 2.9 \\
\hline 10 & Male & $1 \mathrm{Y}$ & 3.000 & 4.7 & 2.7 & 2.7 \\
\hline Mean \pm & & & & $4.940 \pm$ & $3.020 \pm$ & $3.020 \pm$ \\
\hline SD & & & & 1.0157 & 0.5308 & 0.5308 \\
\hline
\end{tabular}




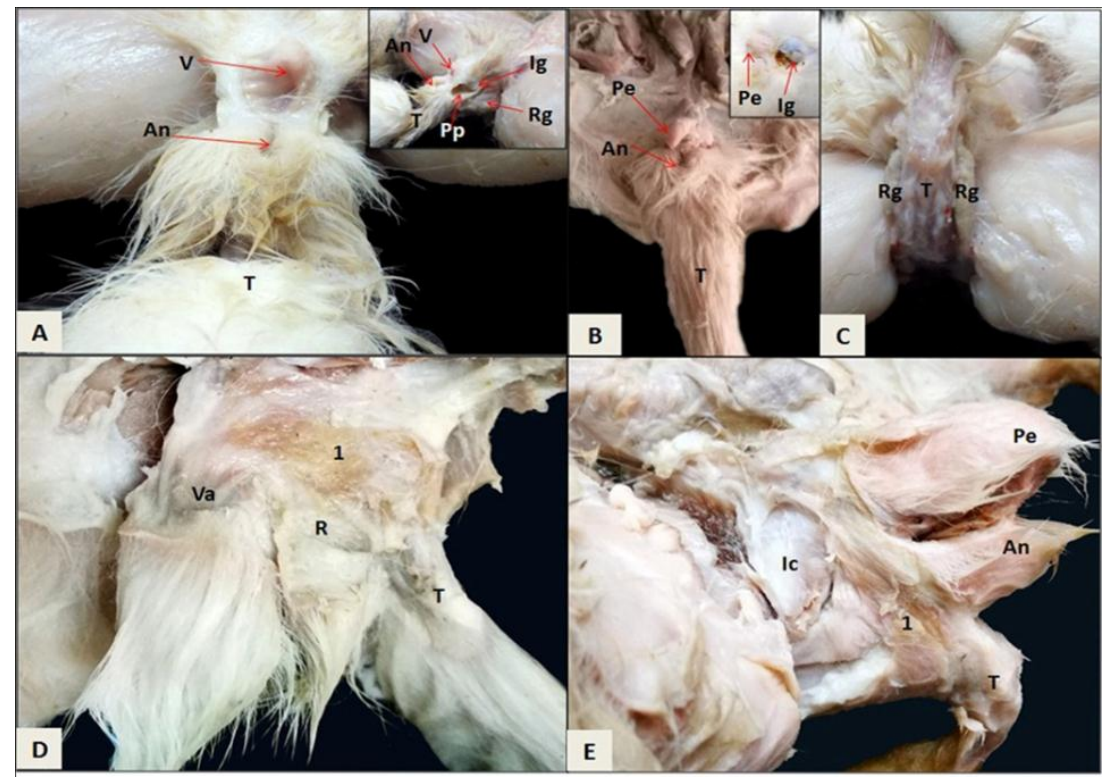

Fig.1. photomacrographs of Caudoventral view of female rabbit (A) with insert showing ventrolateral view of female rabbit, Caudoventral view of male rabbit (B) with the insert showing ventrolateral view of male rabbit, Caudal view of freshly dissected rabbit after reflection of the tail (C), Lateral views of female rabbit (D) and male rabbit (E) showing: V: Vulva, An: Anus, Pp: Perineal pouch, T: Tail, Rg: Rectal gland, Ig: Inguinal gland, Pe: Penis, Va: Vagina, R: Rectum, Ic: M. Ischiocavernosus and 1:M. Levator ani.

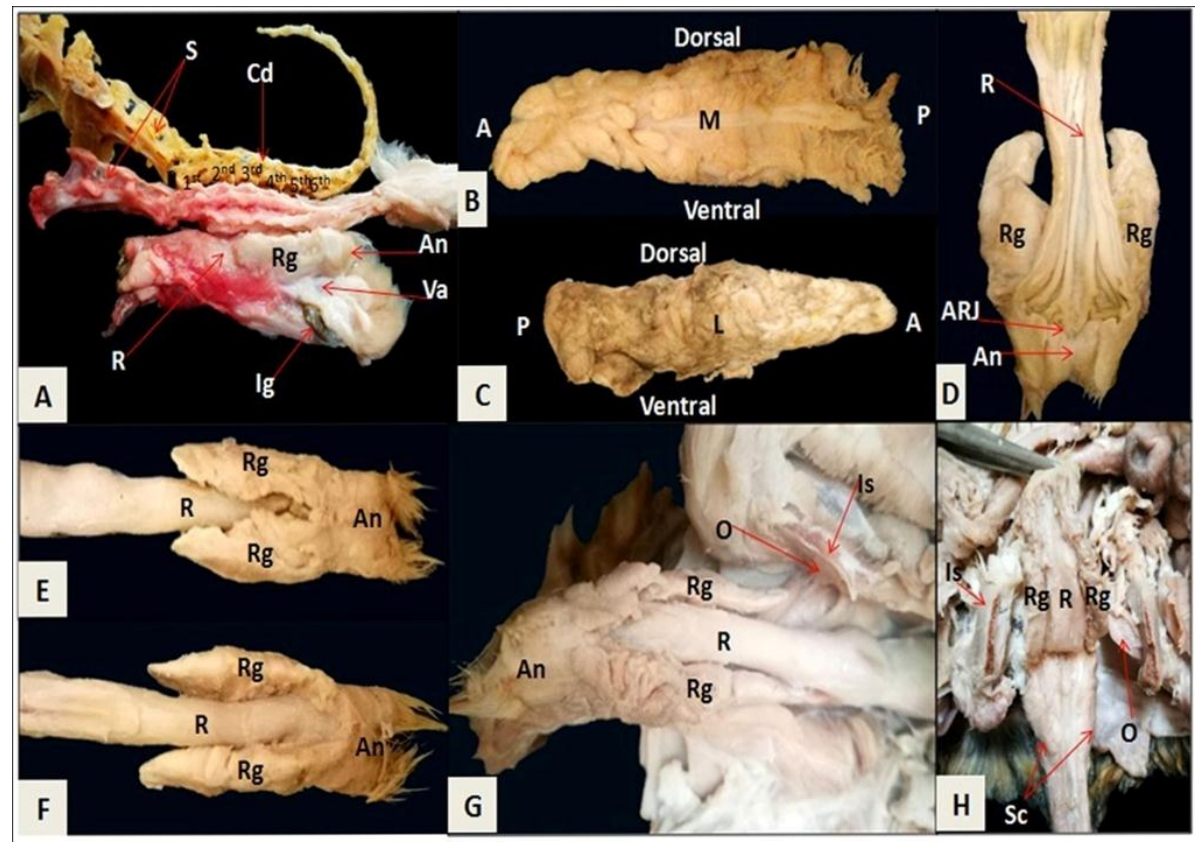

Fig.2. photomacrographs of lateral view of rabbit's rectal gland (in fresh state) showing its relation with the caudal vertebrae (A), medial (B), lateral (C) views of rabbit's rectal gland, dorsal view of rabbit's rectal glands related to opened rectum (D), ventral (E), dorsal (F) views of rabbit's rectal glands and rectum, ventral view of rabbit's rectal glands after cutting off the ischium $(\mathrm{G})$ and caudoventral view of rabbit after reflection of both rectum and glands $(\mathrm{H})$ showing: $\mathrm{S}$ : sacral vertebrae, Cd: caudal vertebrae, An: Anus, Rg: Rectal gland, Ig: Inguinal gland, R: Rectum, Va: Vagina, A: Anterior pole, P: Posterior pole, M: Medial surface, L: Lateral surface, ARJ: Anorectal junction, O: M. obturatorius internus, Is: Ischium and Sc: M.sacrocaudalis ventralis lateralis. 


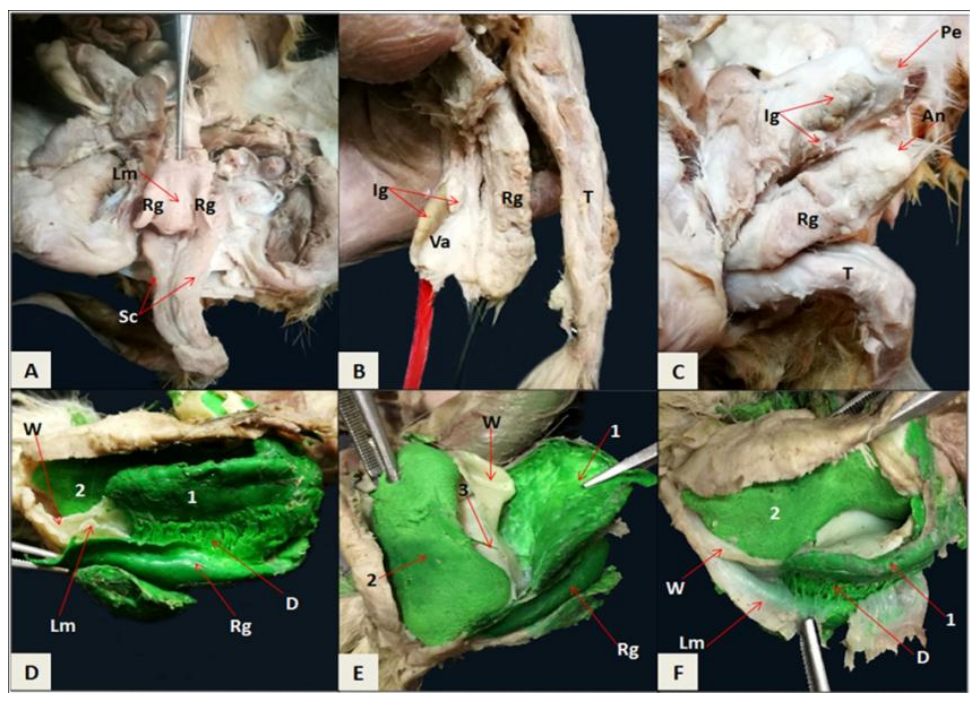

Fig.3. photomacrographs of caudoventral view of rabbit after reflection of both rectum and glands (A), lateral views of female (B), male rabbit (C), dorsolateral (D), caudodorsal (E) and dorsal (F) views of opened injected rectum with gum milk (Latex 60\%) colored green with Scib paints showing: Rg: Rectal gland, Lm: External longitudinal muscles of the rectum, Sc: M.sacrocaudalis ventralis lateralis, An: Anus, , Ig: Inguinal gland, R: Rectum, Va: Vagina, T: Tail, Pe: Penis, W: Wall of the rectum, D: Ducts of the gland, 1: The green latex between the external longitudinal muscle and the wall of the rectum, 2: The green latex inside the lumen of the rectum and 3: The duct to the lumen of the gland.

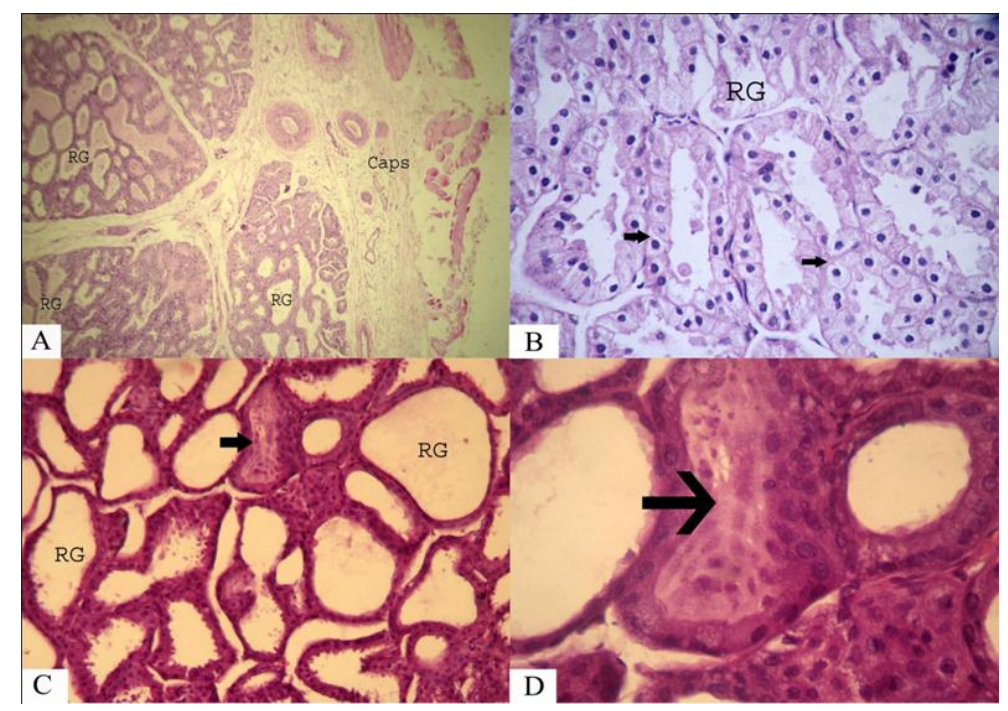

Fig.4. A- A photomicrograph of rabbit's rectal gland showing thick connective tissue capsule (Caps) with few vascularity and thin septa released from it which divided the glands (RG) into many lobules composed of different exocrine secretory unit (acini).Stain: H\&E. Obj.x 10: Oc.x 10 .B- A photomicrograph of rabbit's rectal gland showing many lobules composed of different exocrine secretory unit (acini) which were lined with clear layer of simple cuboidal epithelium with prominent spherical nuclei (arrow). Stain: H\&E. Obj.x 40: Oc.x 10

C-A photomicrograph of rabbit's rectal gland showing some of acini containing secretions in their lumens (arrow) and most of them were free. Stain: H\&E. Obj.x 10: Oc.x 10.

D- A higher magnification of the previous photomicrograph showing the acini with their lining epithelium and their secretions inside the lumens (arrow). Stain: H\&E. Obj.x 40: Oc.x 10. 


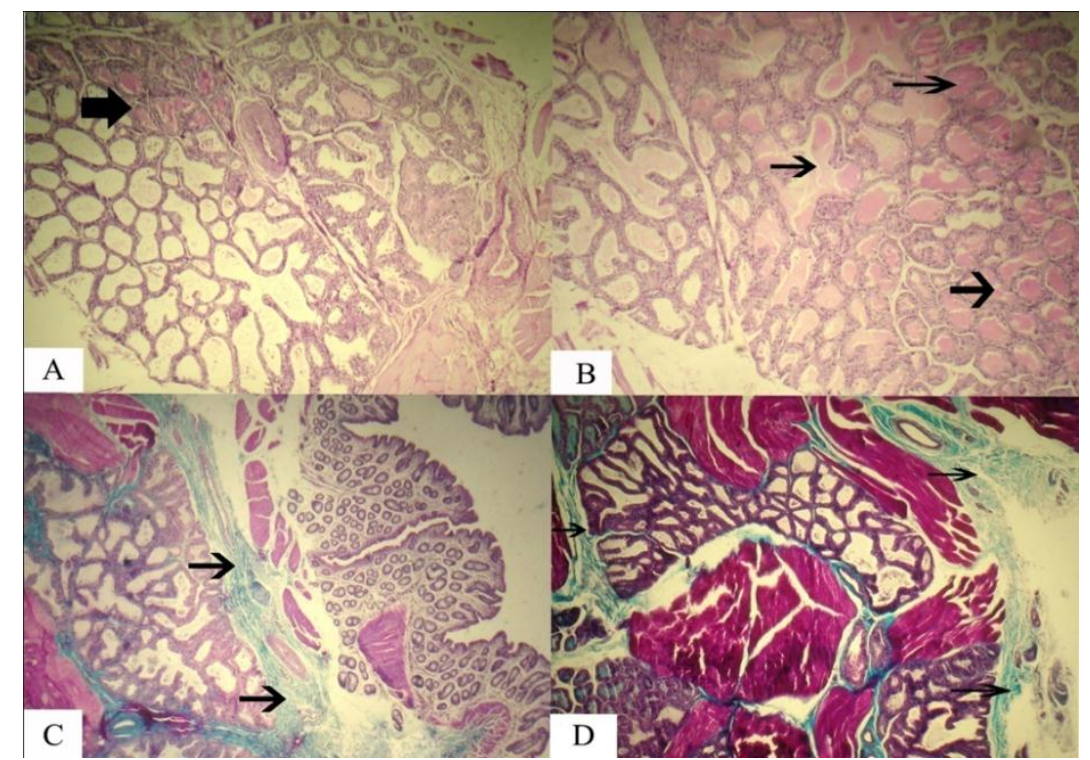

Fig.5. A and B- photomicrographs of rabbit's rectal gland gave positive reactions with PAS (arrows). Stain: PAS technique. Obj.x 10: Oc.x 10.

C and D- photomicrographs of rabbit's rectal gland showing some of collagenic fibers which surrounded the glands (arrows) Stain: Crossmon's trichrome. Obj.x 10: Oc.x 10.

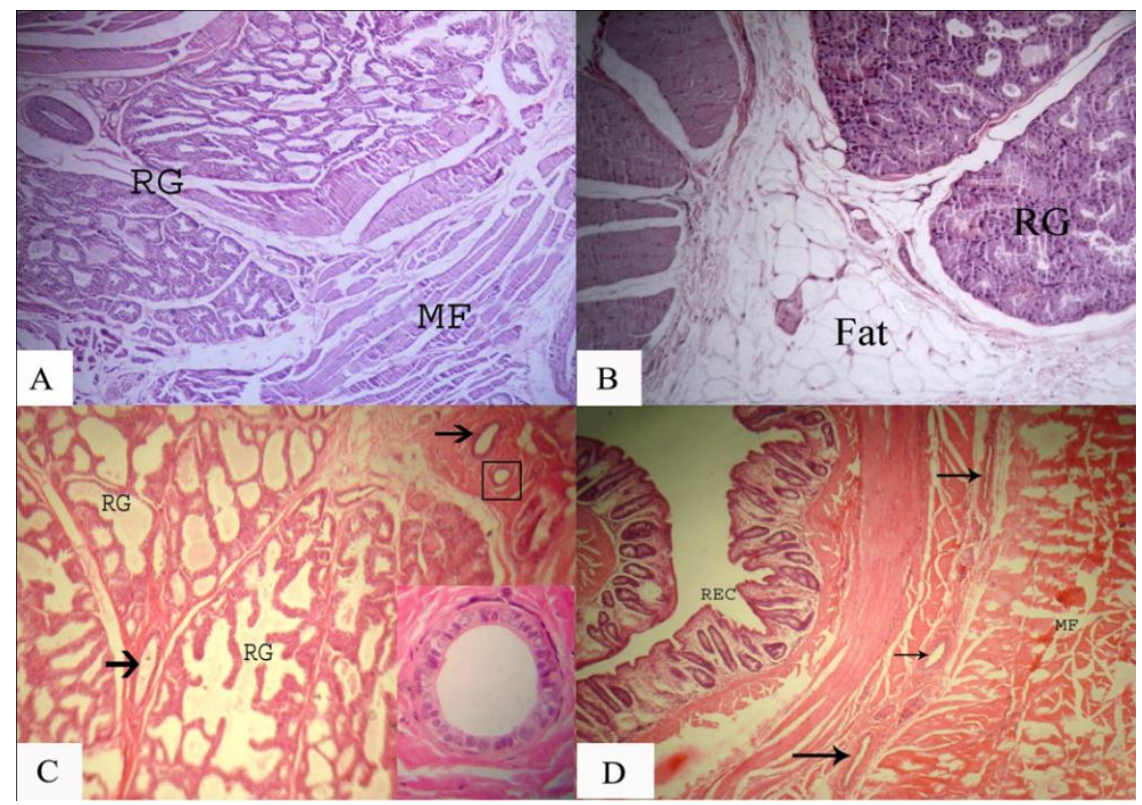

Fig.6. A-A photomicrograph of rabbit's rectal gland (RG) showing the skeletal muscle fibers of the external longitudinal muscle of rectum (MF) Stain: H\&E. Obj.x 10: Oc.x 10.

B- A photomicrograph of rabbit's rectal gland (RG) showing abundant of fat cells (FAT) Stain: H\&E. Obj.x 40: Oc.x 10.

C-A photomicrograph of rabbit's rectal gland $(\mathrm{RG})$ showing its merocrine-type, with interlobular ducts (arrows). Stain: H\&E. Obj.x 10: Oc.x 10 and the squar was higher magnification of the interlobular ducts showing their lining epithilum.

D-A photomicrograph of rabbit's rectum showing the duct system of the rectal gland at the anterior two third of the gland (arrows), rectum (REC) and the skeletal muscle fibers of the external longitudinal muscle of rectum (MF) Stain: H\&E. Obj.x 10: Oc.x 10. 


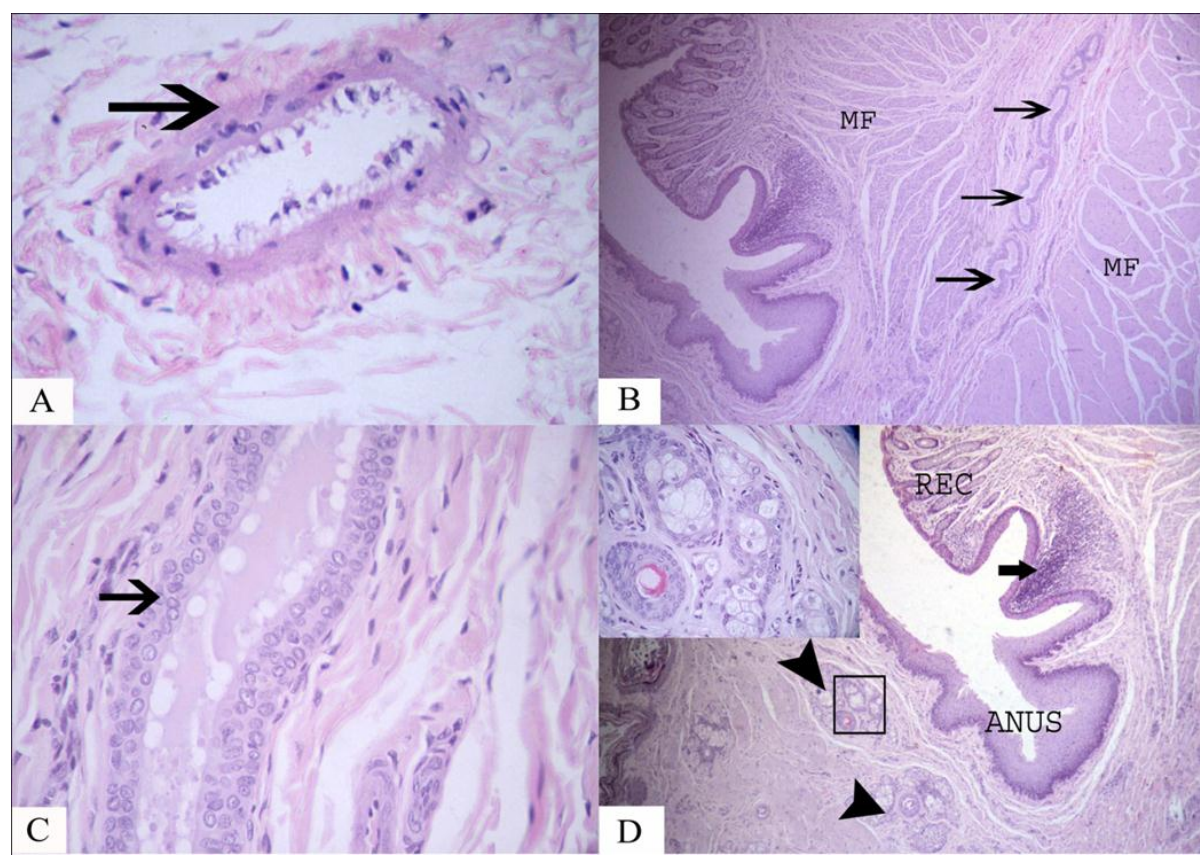

Fig.7. A-A photomicrograph of the duct system of rabbit's rectal gland showing their lining with large number of prismatic epithelial cells containing ovoid nucleus at the anterior two third of the gland either in the capsule or inbetween the skeletal muscle and the wall of the rectum (arrow) Stain: H\&E. Obj.x 40: Oc.x 10.

B-A photomicrograph of the rabbit's ano-rectal junction showing the ducts of the posterior part of the rectal gland (arrows) which were scanty and present between the muscle fibers (MF) and were lined with stratified cuboidal epithelium. Stain: H\&E. Obj.x 10: Oc.x 10.

C- A higher magnification of the previous photomicrograph showing the stratified cuboidal epithelium lined the ducts of the posterior part of the rectal gland (arrow). Stain: H\&E. Obj.x 40: Oc.x 10.

D-A photomicrograph of the rabbit's ano-rectal junction showing lymphatic nodule (arrow), rectum (REC) and modified sebaceous glands (arrow heads) in the anus (ANUS).Stain: H\&E. Obj.x 10: Oc.x 10 and the squar was higher magnification of modified sebaceous glands showing their nature as holocrine glands.

\section{DISCUSSION}

In the present work, the mean length of the rectum was $4.940 \pm 1.0157 \mathrm{~cm}$ which came in the same line with the observations of Huffman (1958) in New Zealand and New Zealand cross bred rabbits. In rabbit, the rectum was the narrow terminal part and opened outside by the anus (Kotpal, 1989). The anal canal was denominated on the terminal part of the rectum which opened to the exterior by the anus (Jordan and Verma, 1983 and Wingerd, 1985). In rabbit, the rectum appeared as a short portion and opened exteriorly through anus (Stan et al., 2014).

In our work, the rectal glands extended laterally on each sides of the rectum and their length represented $61.1 \% \pm 0.061$ of the rectum's length while Martinez-Gòmez, Lucio, Carro, Pacheco and Hudson (1997) pointed to these glands as large anal glands present immediately adjacent to the lateral wall of the rectum. Each gland was about $2.5 \mathrm{~cm}$ long and $0.6 \mathrm{~cm}$ wide. The circumanal 
glands of dog were present around the anus in the cutaneous zone and it was appeared as lobulated modified sebaceous one (Dellmann and Eurell, 1998). The apocrine paranal sinus glands and the sebaceous glands of dogs secreted the malodorous paranal sinus fluid (Stefanov, 2012). In cat, there were two anal sacs which located ventrolateral to the anus between the internal and external sphincters (Maher, El-Sakhawy, Hussein and Shaker, 2015).

According to Table.1, there was a relation between the length of the rectal gland, sex and age of rabbits which similar to the investigations of Dahlbäck and Andersson (1981) and Balah et al., (1986). The size of the anal and inguinal glands in both sexes of wild rabbit in southern Sweden was highly correlated with sexual development. The glands got their maximal size during the intense breeding time, April to August (Dahlbäck and Andersson, 1981).

About the shape and color of the rectal gland, it was elongated oval and it appeared grayish to brownish in color. In balady rabbit, Balah et al., (1986) reported that, the morphology of the gland differed according to age as it formed from four glandular portions and grayish in color at four days of age. At 21 days, the gland became more thicker and longer and with a yellow brownish colour. In three years old rabbit, it was dark brownish and the average length was about two $\mathrm{cm}$.

The presence of $M$. levator ani that encircled the rectum and the rectal gland of rabbit which observed in our paper came in the same line with Palmieri, Panu , Asole , Sanna and Farina (1988) and Nanasaki and Sakuma (2000) and in contrary with Hesterman and Mykytowycz (1968); Bell (1985) and Martinez-Gòmez et al., (1997) who described it as M. constrictor vestibule.
Concerning the type of the rectal gland, in our study, it was merocrine in nature which agreed with the observations of Balah et al., (1986). Moreover the nature of the scent glands differed from species to another and according to its position. Most of mammalian orders had specialized integumentary glands in the anal region termed as anal glands (Schaffer, 1940). In man, there were simple apocrine glands in the axilla and perineal and peri-anal regions however, he didn't have highly developed scent glands (Young, 1957). The anal scent glands of guinea-pig were very large modified sebaceous glands present in between the internal and external sphincter muscles. The glands of the ground squirrel were apocrine type with the predominantly sebaceous type of gland. The armadillo had a complex scent gland (sebaceous and apocrine components) present on either side of the anus. In cat, the scent glands were a pair of complex anal sacs (apocrine and holocrine components). Cattle and pigs had extensive mucus-secreting anal glands associated with a huge arrangement of lymphoid tissue and ramified in the internal sphincter muscle. In sheep and monkeys, no anal glands were detected (McColl, 1965). Some of the anal glands were sebaceous; some were completely apocrine sudoriferous and most likely were mixed. Mammals used the anal glands for active marking behavior (Quay, 1984). In brown brocket deer, there were large well developed sebaceous glands and a moderate numbers of aporcine sudoriferous glands in the skin of the anal region. They were the only source of the powerful musky odor of the fecal pellets of this species (Ajmat, Chamut and Black-Décima, 2004).

As our result, Mescher (2010) reported that, the lamina propria of the recto-anal junction had several free lymphocytes. Also Agarwal et al., (2002) in human, dog and rabbit, confirmed the presence of sebaceous 
glands in the anus that agreed with our investigations. There were sebaceous and apocrine glands in the paranal sacs of cat (Macphail, 2008 and Huston, 2010).

Relating to the microscopic appearance of the gland, the thick connective tissue capsule, the presence of acini and their lining with simple cuboidal epithelium and the skeletal muscle fibers surrounding the gland which analogous to the information obtained by Balah et al., (1986) in balady rabbit.

In our result the ducts of the gland appeared as huge number in the anterior two thirds of the gland and became scanty in the posterior part. While Balah et al., (1986) in balady rabbit, clarified that, the rectal glands opened along the circumference of the rectum by many ducts and differed from our observations in the mechanism of their opening in the lumen of the rectum. In cat, the duct of the anal sac opened near the anocutaneous junction. The secretion of these sacs was probably act as a territorial marker (Maher et al., 2015).

In conclusion, the present results confirmed that the large scent glands on the lateral sides of rabbit's rectum were the rectal glands.

\section{REFERENCES}

Agarwal, K.K.; Agarwal, A.K.; Singh, P.J. and Sharma, S.N. (2002): Comparative Study of Ano-Rectal Region in Mammals. J Anat. Soc. India 51(2): 220-224.

Ajmat, M.T.; Chamut, S. and Black-Décima, P. (2004): A Histological Study of Cutaneous Glands in the Brown Brocket Deer. Acta Theriologica 49(1):93-102.
Balah, A.M.; Ammar, S.M.S.; Bareedy, M.H. and Anis, H. (1986): On the Macroand Micromorphology of Rectal and Inguinal (Brown and White) Glands of Balady Rabbit with Reference to Age Variation. The 9th Egyption Anatomical Soc. Conference.

Bancroft, J. D.; Gamble, M. (2001): Theory and practice of histological techniques. $5^{\text {th }}$ Ed. Churchill Livingstone, Edinburgh, London. Pp.94-282.

Bassett, E.G. (1961): Observations on the Retractor Clitoridis and Retractor Penis Muscles of Mammals, With Special Reference to the Ewe. Journal of Anatomy. 95(1):61-77.

Bell, D.J. (1985): The Rabbits and Hares: Order Lagomorpha. In: Social Odours in Mammals. Brown, R.E., and D.W. MacDonald, eds. Clarendon Press, Oxford. Pp.507-530.

Billen, J. (2009): Diversity and Morphology of Exocrine Glands in Ants. XIX Simposio de Mirmecologia.1-6.

Billen, J. and Morgan, E.D. (1998): Pheromone Communication in Social Insects - Sources and Secretions. In: Vander Meer, R.K.; Breed, M.D.; Winston, M.L. and Espelie, K.E. (Eds), Pheromone Communication in Social Insects: Ants, Wasps, Bees, and Termites. Westview Press, Boulder, Oxford. Pp. 3-33.

Bourliére, F. (1955): The Natural History of Mammals. London, Harrap.

Burger, J.W. (1962): Further Studies on the Function of the Rectal Gland in the Spiny Dogfish. Physiological Zoology. 
Burger, J.W. and Hess, W.N. (1960): Function of the rectal gland in the spiny dogfish. Science, 131, 670-671.

Crossmon, G. (1937): A modification of Mallory's connective tissue stain with a discussion of principles involved. Anat. Rec., 69: 33-38.

Dahlbäck, M. and Andersson, M. (1981): Biology of the Wild Rabbit, Oryctolagus cuniculus, in Southern Sweden.V. Seasonal Variation of Weight of the Anal and Inguinal Glands. Z. Säugetierkunde. 46: 280283.

Dellmann, H. D. and Eurell, J. A. (1998): Text book of Veterinary Histology. 5th Ed. Williams \& Wilkins, Baltimore, Philadelphia, London, Paris, Bankok, Buenos Aires, Hong Kong, Munich, Sydney, Tokyo.

Drury, R.A.B. and Willington, E.A. (1980): Carlton's histological techniques. 5th Ed. Oxford, New York, Toronto, Oxford University Press.Pp.139-198.

Gerzeli, G.; De stefano, G.F.; Bolognani, L.; Koenig, K.W.; Gervaso, M.V. and Omodeo-Salé, M.F. (1976): The Rectal Gland in Relation to the Osmoregulatory Mechanisms of Marine and Freshwater Elasmobranchs. Published in Investigations of the Ichthyofauna of Nicaraguan Lakes, ed. Thomas B. Thorson. School of Life Sciences, University of NebraskaLincoln.

Hall, L.W.; Clarke, K.W. and Trim, C.M. (2001): Veterinary Anaesthesia. 10 ${ }^{\text {th }}$ Edn. WB Saunders. Harcourt Publishers Limited. Pp. $386-404$.

Hesterman, E.R. and Mykytowycz, R. (1968): Some Observations on the Odours of
Anal Gland Secretions from the Rabbit, Oryctolagus cuniculus (L.). CSIRO Wildlife Research. 13:71-81.

Huffman, K.W. (1958): Gross and Histological Studies of the Digestive Tract of the Rabbit. Master Thesis, Kansas State College of Agriculture and Applied Science. Pp.1-16.

Huston, L. (2010): Anal Glands (Anal Sacs) in the Dog and Cat. http://www.pethealthcaregazette.com/2010/01/14/anal -glands-anal-sacs-inthe-dog-and-cat/. (Cited in Maher et al., 2015).

John, F. and Ebling, G. (1988): Scent Glands in Mammals: Social Functions and Implications of Apocrine Gland Odours. J. Appl. Cosmetol. 6: 1-14.

Jordan, E. L. and Verma, P. S. (1983): Chordate Zoology and Elements of Animal Physiology. $5^{\text {th }}$ ed. S. Chard \& Company Ltd. Ram Nagar. New Delhi. Pp. 728-754.

Khoo, C.C.H and Tan, K.H. (2005): Rectal Gland of Bactrocera papayae: Ultrastructure, Anatomy, and Sequestration of Autofluorescent Compounds Upon Methyl Eugenol Consumption by the Male Fruit Fly. MICROSCOPY RESEARCH AND TECHNIQUE. 67:219-226.

Kiernan, J. A. (2008): Histological and histochemical methods: Theory and Practice, 4th Ed, Scion Publishing Ltd. University of western ontario,London, Canada.

Kotpal, R.L. (1989): Modern Text Book of Zoology In: vertebrate. Rastogi publication, Merut. 318-499. 
MacPhail, C. (2008): Anal Sacculectomy. CompendContin. Educ. Vet. Oct. 30(10):E9.

Maher, M. A.; El-Sakhawy, M. A.; Hussein, S. and Shaker, N. A. (2015): Morphological Studies on the Anal Canal of Adult Male Cat (Felis domestica). Int. J. Adv. Res. Biol. Sci. 2(3): 195-205.

Martinez-Gòmez, M.; Lucio, R.A.; Carro, M.; Pacheco, P. and Hudson, R. (1997): Striated Muscles and Scent Glands Associated With the Vaginal Tract of the Rabbit. The Anatomical Record. 247:486-495.

McColl, I. (1965): The Comparative Anatomy and Pathology of Anal Glands. Arris and Gale Lecture delivered at the Royal College of Surgeons of England. Pp. 36-67.

Mclaughlin, C.A. and Chiasson, R.B. (1979): Laboratory Anatomy of the Rabbit. Second Edition. Wm.C.Brown Company publishers.Pp:35-36.

Mescher A.L. (2010): Junqueira's Basic histology. Twelfth Ed. The McGrawHill companies, USA.

Mykytowycz, R. (1966): Observations on Odoriferous and Other Glands in the Australian Wild Rabbit, Oryctolagus cuniculus (L.) and the Hare, Lepus europaeus P. I.The Anal Gland. CSIRO Wildlife Research. 11: 11-29.

Mykytowycz, R.; Hesterman E.R.; Gambale, S. and Dudzinski, M.L. (1976): A Comparison of the Effectiveness of the Odors of Rabbits, Oryctolagus cuniculus, in Enhancing Territorial Confidence. J. Chem. Ecol., 2(1): 1324.
Nanasaki, Y. and Sakuma, Y. (2000): Perineal Musculature and Its Innervation by Spinal Motoneurons in the Male Rabbit: Effects of Testosterone. J.Nippon.Med.Sch.67(3):164-171.

Nomina Anatomica Veterinaria (2012): 5th edition, prepared by the International Committe on Veterinary Gross Anatomical Nomenclature (I.C.V.G.A.N.) and authorized by the General assembly of the World Association of Veterinary Anatomists (W.A.V.A.), konxville,T.N (USA). Published by the Editorial Committee, Hannover, Columbia, Ghent and Sapporo. Pp:39-43.

Palmieri, G.; Panu, R.; Asole, A.; Sanna, L. and Farina, V. (1988): Coccygeus and Levator Ani Muscles in the Rabbit: Morphology and Proprioceptive Innervation. Biol Struct Morphog. 1(4):142-146.

Parks, A.G. (1961): Pathogenesis and Treatment of Fistul-in-Ano. British. Med. J. 1: 463-469.

Quay, W.B. (1984): Scent Glands in the Skin of Mammals. In Bereiter-Hahn J.; Matoltsy, A.G. and Richards, K.S. Biology of the Integuments: 2 Verterbrates. $1^{\text {st }}$ Ed. Springer-Verlag Berlin Heidelberg New York Tokyo. Pp. 357-369.

Schaffer, J. (1940): Die Hautdrüsenorgane der Säugetiere. Urban \& Schwarzenberg, Berlin. (Cited in Quay, 1984).

Stan, F.; Damian, A.; Gudea, A.; Dezdrobitu,C.; Bob, D.; Martonos, C.; Bochis, I and Pogana, B. (2014): Comparative Anatomical Study of the Large Intestine in Rabbit and 
Chinchilla. Bulletin UASVM

Veterinary Medicine. 71 (1):208-212.

Stefanov, I. S. (2012): A Study on Paranal Sinus Micromorphometrical Parameters in Dogs of Different Ages. Turk. J. Vet. Anim. Sci. 36(3): 267274.

Takaki, S. and Tagawa, M. (1961): Hard and Soft Faeces of the Rabbit and Their Relation to the Anal Gland Secretion and the Contents of the Caecum. Jap. J. Zool. 70: 248-252.

Wigglesworth, V.B. (1965): The Principles of Insect Physiology. Mathuen and Co. Ltd London. Pp. 741.

Wingerd, B.D. (1985): Rabbit Dissection Manual. The Johns Hopkins, University Press .Baltimore. Pp.46. 